never really existed. Campaigns like that by the UK government against the IRA may not have had the body-count of the Iraq or Afghanistan campaigns, but for illiberal politics they could also boast detention without trial, suspension of basic civil liberties, torture, extrajudicial killing, complicity with paramilitary organisations and a management of a climate of fear in justification of constitutional vandalism that this work tends to see as unique to the war on terror.

Politics Most Unusual is, therefore, a significant contribution to the substantial literature taking a broadly 'critical' perspective on the nature of post-9/11 politics. Its key strength is the engagement with a psychoanalytic approach to understanding the nature and significance of neglected aspects of religion and prejudice in contemporary political life and the ways in which 'spin', dissimulation and straightforward lying have ceased to be the mortal sins of politics that they once were. The authors deserve credit for this significant contribution to debate in this field.

John Williams

School of Government and International Affairs,

Durham University, UK

\title{
Anarchism and utopianism
}

Laurence Davis and Ruth Kinna (eds.)

Manchester University Press, Manchester, 2009, xvi + 285pp., $£ 60.00 / \$ 90.00$, ISBN: 978-0719079344

Contemporary Political Theory (2012) 11, e3-e5. doi:10.1057/cpt.2010.31

This volume collects 14 essays that, in various (and very diverse) ways, explore the relationship between the terms of the title. As one of the editors (Davis) states in the introduction, the essays fall generically into two categories: first, broadly philosophical papers that explore the historical trajectory of the relationship between the two concepts, and second chapters that examine cases where the traditions are configured in a particular fashion. The volume itself is divided up rather differently, with five thematic sections of varying length.

What is the collection intended to achieve? Davis tells us that the book is not intended to be comprehensive, but the hope is that it will stimulate 'further reflection and informed dialogue' (5) about the subject. Both this editor and a number of the contributors hold that anarchist politics have been given added 
impetus in recent years with the rise of the alter-globalisation movement and what they see as a growing disenchantment with liberal-democratic capitalist systems around the world.

A number of common themes emerge through the chapters, despite the variety of topics covered. One of the most persistent is the view that there are different types of utopian politics, and that one element that marks contemporary anarchist politics is its rejection of 'bad' forms of utopia. While Clark in his synoptic chapter identifies five variants of utopianism, most of the authors who make a distinction operate with a broad dichotomy between static, future-orientated, perfectionist, prescriptive, 'blueprint' forms of utopia, and dynamic, open, liberatory, process-based, and critical forms of utopia. The former type of utopia seeks to force social change into the procrustean bed of a future-orientated social imaginary. The remainders have to be made to fit, and this is what can give us utopia with gulags. Open, process-based utopias, on the other hand, tend to revolve around prefigurative forms of politics whereby activists seek to 'be the change' and open up a space for critical engagement with the existing order. Two questions arise, however. First, once you endorse this second, open view, what remains distinctively utopian about the politics on offer? Utopianism seems to collapse into a form of critical theory whereby the project 'is not one of rejecting the past in favour of an imagined future, but of transforming the present as part of an organic process in which already existing tendencies are built on' (244). Furthermore, if that is the case, how do we know which tendencies to select for further development? This problem rears up in Newman's contribution, when he discusses how the new politics 'affirms a kind of radical disruption of the current order through the invoking of the idea of an alternative, without at the same time setting out what that alternative actually is' (216). He notes that this may be a weakness as well as a strength, but it also might be considered little more than empty posturing, it being all too easy to be 'radical' and 'disruptive' if you do not have to make the intellectual effort to propose a viable alternative to the prevailing system. It is also worth asking whether this good/bad utopia distinction shows that, as a value, 'utopia' is entirely parasitic upon other values. If a utopia embodies freedom, equality, lack of hierarchy and so on it is 'good', but only to the extent that it manifests those other values. If it is closed, hierarchical, dictatorial, repressive and so on it is 'bad', but again, merely because it is a vehicle for negative values. It is not clear what independent work the notion of utopia actually performs in the evaluation of anarchism or any other ideological form.

Another element that unites most essays here is a strident rejection of the prevailing liberal democratic/capitalist political and economic system. The contributions are not merely scholarly, they are 'socially engaged'. Davis' own chapter is, he tells us, 'intended as a contribution to the revolutionary project of constructing a sustainable anarchist utopian counter-cultural challenge to 
the capitalist form of archist domination that has so disfigured our world and the lives of all those who inhabit it' (74). Therefore, this is an ideological as well as scholarly project (or perhaps not scholarly at all, if one has certain views on the relationship between scholarship and the naked pursuit of political intent). From such a perspective liberal-capitalism gets short shrift. Marshall's preface sets the tone - 'work hard now, defer joy, consume as much as you can, obey your rulers and all shall be well. This is the dead-end that liberal democracy serving capitalism has to offer' (xiv). For Clark 'totalitarianism reaches its greatest perfection in the utopia of consumption' (13). To object that a trip to the local Tesco, while far from a utopian experience in itself, seems infinitely preferable to a few years in a Soviet Gulag would of course be naive in the extreme, as the totalitarianism of consumption does not need such crude devices to enforce itself, attaining 'capture the imagination' (13) instead. The alternative, as posited in the Daodejing, sees 'a world in which humanity and nature are in harmony, in which human beings live together peacefully and cooperatively, and in which universal self-realisation is fostered' (11). This, surely, is all too easy. For the defence, capitalism - a complex and multifaceted phenomenon - has shown an astonishing ability to lift billions of people out of poverty in the past couple of hundred years, and it is technologically fecund (for all its glaring faults), but why let such complexity get in the way of a good revolutionary contribution?

This is a book for those already convinced that the relationship between anarchism and utopia is both interesting and important, and the essays by Kinna, Newman, Suissa and Gordon all make contributions to understanding the politics of this. For those not so convinced, there is nothing here to tell them why they should be.

Mathew Humphrey

School of Politics \& IR, University of Nottingham, UK

\title{
Women's rights as multicultural claims: Reconfiguring gender and diversity in political philosophy
}

\author{
Monica Mookherjee
}

Edinburgh University Press, Edinburgh, 2009, xvi + 192pp., £60.00, ISBN: 978-0748632794.

Contemporary Political Theory (2012) 11, e5-e7. doi:10.1057/cpt.2010.32 